\title{
Arctic shelf development as a driver of the progress of the Russian energy system
}

\author{
Elena S. Balashova ${ }^{1}$, and Elizaveta A. Gromova ${ }^{1 *}$ \\ ${ }^{1}$ Peter the Great St. Petersburg Polytechnic University, Saint-Petersburg, Russia
}

\begin{abstract}
Today many countries are concerned about the Arctic, including ones which are rather distant from it. High prospectively of the region in the context of undiscovered oil and gas resources is the explanation of this interest. Russia possessing the most significant part of these reserves has a fairly low rate of exploration of the Arctic shelf. Arctic hydrocarbon resources play the important strategic role in the development of the fuel-energy complex of Russia, ensuring its energy security. Therefore, the aim of this study is to identify effective model of development of the offshore fields in the Arctic zone of the Russian Federation. The model of the creation of consortia for the development of the offshore fields is analyzed and it is considered in the context of the Russian Arctic. The conclusion about the efficiency of the application of this model is done.
\end{abstract}

\section{Introduction}

In recent years, due to emerging trends in the international community and strong support at the state level, the Arctic is becoming a strategically important object for Russia. In February 2013, the Russian President approved the development Strategy of the Arctic zone of the Russian Federation and national security for the period up to 2020. Plans of expanding Russia's military presence in the Arctic are the essential part of this document. But also the significant attention is given to the issues of sustainable socio-economic development of the Arctic zone of the Russian Federation. In this area, the state of the fuel and energy complex plays an important role. World oil consumption becomes commensurate with its production (at the end of 2015: 32,4 billion barrels/ 32.7 billion barrels) [1].

According to the OPEC and the International energy Agency, primary energy consumption will increase by $40-60 \%$ in 2040 compared to 2010 . While in the global energy mix oil will continue to take a leading place - its share will account for $25-27 \%$, and the share of gas $-24-26 \%$ versus $35 \%$ and $26 \%$, accordingly. Forecasted volume of undiscovered Arctic continental shelf reserves is estimated at 90 billion barrels of oil and 47 trillion cubic meters of natural gas [2]. According to these estimates, offshore oil and gas resources in the Arctic in the medium and long term can play a significant role in maintaining the current level of hydrocarbon production and its growth. Russia also has the

* Corresponding author: lizaveta-90@yandex.ru 
largest share of oil and gas resources: $41 \%$ of the undiscovered technically recoverable resources of oil and $70 \%$ of the gas [3]. Arctic hydrocarbon resources constitute a strategic reserve of the fuel and energy complex of Russia, ensuring its energy security. That's why there is an actuality for realizing of the actions for the development of Arctic offshore fields at the present time and it is one of the main long-term directions for sustainable development of Russia's energy policy.

Especially, taking into account the exhaustion of the known Russian oil fields, if the current rate of production continues, the reserves on the mainland will be developed in 30 years [4]. Consequently, the goal of the study is to identify the most optimal model of the development of the offshore fields in the Arctic zone of the Russian Federation.

Many scientists engaged in the theoretical and practical issues of the development of the Arctic as a strategically important object. Among them are the following scientists: M. V. Remizov (2015), A. B. Zolotukhin (2016), I. V. Panichkin (2015), V. I. Bogoyavlenskii (2013; 2014), I. V. Bogoyavlenskii (2014), O. I. Suprunenko (2014), A.V. Ryzhova (2016), who focus on the research of the Russian part of the region, and A. Saburov (2013), V. Koptelov (2012), V. Konyshev and A. Sergunin (2012; 2015), R.J. Hasle, U. Kjellén и О. Haugerud (2009), D. Gautier (2009), Ø. Harsem, A. Eide и K. Heen (2011), A. Mikkelsen и О. Langhelle (2008), P. Johnston (2010), who study foreign parts of the Arctic. It is noteworthy that, according to these experts, Norway is the country that pursues the most consistent and rational policy in the region. However, the question of the practical application of the Norwegian experience for the Russian Arctic shelf is not well explored.

\section{Experimental section}

The Arctic is a specific region, requiring the creation of a sophisticated complex of measures on development at the state level. Direct access to the Arctic ocean have 5 countries: Russia, USA, Canada, Norway and Denmark (Greenland), but only three of them, the U.S., Norway and Russia engaged in the production of hydrocarbons. Although optimally constructed policy in the development of the Arctic shelf is typical for all countries with the exception of Russia.

\subsection{The creation of consortia for the development of the offshore fields}

Public policy based on the creation of consortia for the development of the offshore fields $[5,6,7,8,9,10]$, has successfully established itself in the countries near the Arctic, particularly in Norway.

The essence of the methodology consists in the temporary union of two or more large companies to implement a major project on pre-agreed conditions where the role of the state may lie in the selection of the so-called pre-qualification of participants.

Moreover, state structures and state-owned companies may not be part of the consortium. It should be noted that oil and gas companies that are striving to develop the Arctic shelf, must not only be able to work on the shelf, but it also requires special skills and technologies for working in high latitudes. Specificity of the Arctic oil and gas technologies is determined by three key challenges: ice conditions, limited space to implement workflow, and the need for rapid and effective response to potential oil spills.

Higher requirements on reliability and resistance to climatic conditions apply to the technical means of reconnaissance and development of the offshore fields in conditions of freezing temperatures.

Overall, the works on the shelf contain the following potential risks - natural, technical, infrastructural, environmental (table 1). 
Table 1. The potential risks of the Arctic shelf development.

\begin{tabular}{|c|c|}
\hline Risk group & Problems \\
\hline Natural & $\begin{array}{ll} & \text { extremely low temperatures; } \\
\text { - } & \text { strong wind; } \\
\text { - } & \text { floating icebergs; } \\
\text { - } & \text { year-round freezing waters; } \\
\text { - } & \text { lack of the knowledge of shelf; } \\
\text { - } & \text { shallow near-bottom deposits of free gas; } \\
\text { - } & \text { abnormally high formation pressure. } \\
\end{array}$ \\
\hline Technical & $\begin{array}{l}\text { - availability of the specialized equipment; } \\
\text { - } \quad \text { availability of the liquidation technologies of consequences of oil spill. }\end{array}$ \\
\hline Infrastructural & $\begin{array}{l}\text { lack of the coastal transport infrastructure; } \\
\text { - lack of the infrastructure logistics; } \\
\text { - the short duration of the navigation period. }\end{array}$ \\
\hline Environmental & $\begin{array}{l}\text { - } \begin{array}{l}\text { consequences of a possible oil spill; } \\
\text { presence of the numerous burials of nuclear waste on the seabed } \\
\text { (particularly the Kara Sea). }\end{array} \\
\end{array}$ \\
\hline
\end{tabular}

Indicated risk groups, confirm a high degree of complexity of the task of development of the Arctic shelf and thereby prove the importance of choosing the most optimal model of operations in this area.

The positive effect of the Norwegian model for creation of consortia for development of the Arctic offshore fields is confirmed by examples of countries that widely use this model. So, in Norway in recent time, due to the fall in production at the major oil fields in the North Sea and in the Norwegian Sea, the government has stepped up its efforts to attract oil companies to develop oil and gas resources in the Barents Sea. At the current time one field "Snøhvit" with reserves of 193 billion cubic meters of gas and 113 million barrels of gas condensate is located in the industrial exploitation of the Arctic continental shelf of Norway. It was opened in 1984 in $150 \mathrm{~km}$ from the Norwegian coast, gas production began here in 2007. Industrial complex, consisting of 19 production wells, wells for injection of carbon dioxide, a pipeline with a length of $160 \mathrm{~km}$ and complex "Hammerfest LNG" with a capacity of 4,3 million tones of liquefied natural gas per year, was built to develop the field. Operator is the company "Statoil", whose share in the project is 33,53\%. The project of development of the oil deposit "Goliat" is in the final stage of the commissioning. The field was discovered with reserves of 174 million barrels of oil and 8 billion cubic meters of gas in 2000. In spring of 2015 floating platform FPSO Sevan 1000, which will also be used as storage for 1 million barrels of oil and a floating terminal at the time of shipment, was delivered here [5].

In 2012 in Denmark, the consortium of oil companies composed of ConocoPhillips (USA), the "GDF Suez" (France), "Nunaoil" (Greenland), "Maersk" (Denmark), Statoil (Norway), "Cairn Energy" (Scotland) and Shell (Netherlands, operator) was created. As a result, 11 of exploration wells in shallow water in Baffin Bay were drilled, but no commercial reserves of oil could not be found. In 2016-2018, the government of Greenland plans to auction a number of licenses on the West coast of the island [11].

In 1997, the government of Canada resumed issuing licenses for exploration in the Beaufort Sea. Further licenses were granted to American companies "Burlington Resources" (in 2006 bought "ConocoPhillips"), "Anadarko", "Chevron", "ConocoPhillips", "Devon", to British companies - "Shell", "BP", "Franklin Petroleum," to Canadian 
companies - "Petro-Canada", "Imperial Oil", "MGM Energy" and "Encana". The results of exploratory drilling conducted by "Devon" in the period 2005-2006 in the Bay Beluga in the Beaufort Sea, showed the presence of recoverable hydrocarbon reserves, but not enough to start commercial development. Currently, several consortia: "Imperial Oil", "BP" and "ExxonMobil"; "Chevron" and "Statoil" were created with the aim to start joint drilling presumably in 2020 [12].

Nowadays, production of only oil and only in the Beaufort Sea is carried out on the Arctic continental shelf of the United States - either from the mainland with the help of horizontal drilling, or artificial islands built on shallow depths (up to $10 \mathrm{~m}$ ). Now the company "Shell" rents the largest number of the sites in the Beaufort Sea and in the Chukchi Sea. In addition, «Statoil» (Norway), «BP» (England), «ConocoPhillips» (USA), «Eni» (Italy), «Murphy Oil Corporation» (USA), «Iona Energy» (Canada), «OOGC America» (subsidiary of the China national petroleum Corporation) and «Repsol» (Spain) act as tenants. Oil and gas companies adhere to the strategy of the gradual development of the Arctic fields with the aim of creating appropriate infrastructure in the region to be fully prepared by the beginning of the "Arctic boom", which will probably take place before 2050 [13].

\section{Results and Discussion section}

The Russian Arctic shelf is characterized by a very low degree of the geological knowledge, along with the above-mentioned leading role in the share of the undiscovered oil and gas reserves. At the same time, some experts give more restrained forecasts in this regard $[14,15,16]$. However, the development of the Arctic shelf is recognized as a promising and relevant problem is formulated at the state level. According to made estimates, investment roughly equal to a trillion of dollars will be needed for the exploration of the Russian part of the Arctic shelf by 2050 [17].

In 2008, changes that limit the number of companies who may be granted licenses to use subsoil of the continental shelf of the Russian Federation, including the Arctic were made to the Federal law of the Russian Federation "On subsoil" (of 21 February 1992). As a result, users of subsoil on the Arctic shelf of Russia can be companies with state participation $50 \%$ and over five years of experience in this field. Only the companies "Gazprom" and "Rosneft" meet these requirements. Private companies are allowed to the Russian shelf only in joint ventures (accordingly, with a share of less than 50\%). Recently, the question of the admission of the private companies to the development of Russian resources in the Arctic zone is discussed quite often. In early 2015, the Ministry of natural resources and ecology of the Russian Federation made a proposal to allow private companies to the shelf, temporarily halting the issuance of licenses to the state-owned companies, thus trying to replicate the model to create consortia for the development of the offshore fields. But the consideration of this issue at the government level, has been repeatedly postponed.

At the moment, almost all of the promising areas of the Arctic shelf are covered by the licenses of the companies "Gazprom" and "Rosneft", which are not able to carry out a full study on its own. Development of the oil field "Prirazlomnoye" opened in 1989 in the Pechora Sea is the first and only oil and gas project in the Russian Arctic shelf. The reserves of the field are estimated of 72 million tons of oil. The company "Gazprom Neft shelf" has the license for its development. In 2011, the offshore ice-resistant oil platform "Prirazlomnaya" with a design capacity to 6,5 million tons per year was delivered here. In 2013 commercial development of the deposit began. And in 2014, 300 thousand tones of the oil «Arctic Oil» (approximately 2,2 million barrels) from the platform was shipped and 
delivered to the port of Rotterdam. By 2021 it expects to get 5-5,5 million tones of the oil per year [18].

The main positive and negative aspects of the implementation model for creation of consortia in the Arctic zone of the Russian Federation are highlighted in the table 2.

Table 2. The main advantages and disadvantages of applying the model on creation of consortia in the Arctic zone of the Russian Federation.

\begin{tabular}{|c|c|}
\hline Advantages & Disadvantages \\
\hline $\begin{array}{l}\text { - ability to neutralize the anti-Russian sanctions; } \\
\text { - } \\
\text { - } \\
\text { - } \\
\text { high levibility of achieving of the motivation of each participant of } \\
\text { the consortium; } \\
\text { ability to implement projects that require large } \\
\text { investments; } \\
\text { Russia is not ready to implement a independent set } \\
\text { of events (the lack of the required technical and } \\
\text { technological level, extremely low level of scrutiny } \\
\text { of the shelf; only by } 2020-2025 \text { Russia will be able } \\
\text { to overcome the high degree of dependence from } \\
\text { western countries in this direction) [19]; } \\
\text { the mechanism of the state-private partnership is } \\
\text { appropriate, taking into account the immensity of } \\
\text { the tasks; } \\
\text { relevance of the strengthening the cooperation of the } \\
\text { Arctic States and interested oil and gas companies. }\end{array}$ & $\begin{array}{l}\text { - admission of the private } \\
\text { companies on the shelf is a step, } \\
\text { opening the way for foreign } \\
\text { transnational corporations, } \\
\text { which do not need to be in the } \\
\text { form of a partner, neither } \\
\text { «Rosneft» nor «Gazprom»; } \\
\text { high price of the private } \\
\text { companies' mistakes for } \\
\text { Russia; } \\
\text { motivation of the private } \\
\text { companies is one-sided and has } \\
\text { nothing to do with national } \\
\text { interests; } \\
\text { the most negative outcome is } \\
\text { the loss of a part of the deposits } \\
\text { of the Russian Arctic shelf. }\end{array}$ \\
\hline
\end{tabular}

In quantitative and qualitative equivalent the advantages of the application of the Norwegian experience in creating consortia in the context of the Arctic zone of the Russian Federation surpassed the disadvantages. Like any mechanism, the idea of consortia has a number of, rightly pointed out weaknesses, united by a common fear, which is unacceptable at the present stage of the development.

In general, despite the objective difficulties, the development of Arctic oil and gas resources remains a strategic priority for Russia. The model for the creation of consortia is an effective step towards the achievement of success in solving this problem.

\section{Conclusions}

Summing up the results of the study, the following conclusions can be made:

1) the set of the activities associated with the target study and the subsequent collection of works on the Arctic shelf is a challenging task due to the specificity of the region;

2) the state approach to a large-scale project for the development of the Arctic shelf, which has a high proportion of the undiscovered oil and gas resources based on the application of the model for the creation of consortia, will create conditions for an economic breakthrough of Russia;

3) an extremely low percentage of exploration of the Arctic shelf provokes urgent and decisive steps to overcome the gap in this part from other Arctic nations; 
4) development of the Arctic will give impetus to the progress of many domestic industries and ensure energy security of Russia in the future.

\section{References}

1. URL: http://www.ereport.ru/articles/commod/oilcount.htm (accessed 16.03.2017)

2. D. Gautier, Science, Assessment of Undiscovered Oil and Gas in the Arctic, 324 (5931), 1175-1179 (2009)

3. URL: https://spb.riss.ru/analytics/4303/ (2016)

4. URL: http://sever-press.ru/vse-novosti/item/22137-osvoenie-arkticheskogo-shelfastanet-prioritetnym-dlya-rossii (accessed 16.03.2017)

5. URL: http://russiancouncil.ru/inner/?id_4=2608\#top-content (2013)

6. R.J. Hasle, U. Kjellén, O. Haugerud, Safety science, 47(6), 832-842, (2009)

7. Ø. Harsem, A. Eide, K. Heen, Energy Policy, 39(12), 8037-8045, (2011)

8. A. Mikkelsen, O. Langhelle, Arctic oil and gas: sustainability at risk? (2008)

9. P. Johnston, Journal of Military and Strategic Studies, 12(2), 234-244 (2010)

10. URL: http://russiancouncil.ru/arcticoil (accessed 16.03.2017)

11. URL: http://russiancouncil.ru/inner/?id_4=308\#top-content (accessed 16.03.2017)

12. URL: http://russiancouncil.ru/inner/?id_4=835\#top-content (accessed 16.03.2017)

13. URL: http://russiancouncil.ru/inner/?id_4=6423\#top-content (accessed 16.03.2017)

14. V.I. Bogoyavlenskii, I.V. Bogoyavlenskii, Vestnik MSTU, 17(3), (2014)

15. V.I. Bogoyavlenskii, The Arctic: ecology and economy, 2(10), (2013)

16. O.I. Suprunenko, The Arctic: ecology and economy, 3, (2014)

17. A.B. Zolotukhin, Priorities of Russia in the Arctic (2016)

18. M.V. Remizov, Russia in the Arctic. Challenges and prospects of the development, (2015)

19. URL: http://pro-arctic.ru/23/11/2015/resources/19076 (accessed 16.03.2017) 